\title{
Growth and Yield of Six Soybean Genotypes on Short-term Flooding Condition in the Type-B Overflow Tidal Swamps
}

\author{
Pertumbuhan dan Produksi Enam Genotipe Kedelai pada \\ Genangan Sesaat di Lahan Pasang Surut Tipe Luapan B
}

\section{Danner Sagala $^{1,2}$, Munif Ghulamahdi ${ }^{3}$, Trikoesoemaningtyas ${ }^{3}$, Iskandar Lubis ${ }^{3 *}$, Tatsuhiko Shiraiwa ${ }^{4}$, and Koki Homma ${ }^{5}$}

\author{
${ }^{1}$ Agronomy and Horticulture Study Program, Graduate School, Bogor Agricultural University (IPB) \\ ${ }^{2}$ Agrotechnology Study Program, Faculty of Agriculture, Universitas Prof. Dr. Hazairin SH \\ Jl. Jenderal Sudirman No. 185, Bengkulu 38000, Indonesia \\ ${ }^{3}$ Department of Agronomy and Horticulture, Faculty of Agriculture, Bogor Agricultural University (IPB) \\ Jl. Meranti, IPB Dramaga Campus, Bogor 16680, West Java, Indonesia \\ ${ }^{4}$ Graduate School of Agriculture, Kyoto University, Kitashirakawa Oiwake-cho, Sakyo-ku, Kyoto 606-8224, Japan \\ ${ }^{5}$ Graduate School of Agricultural Science, Faculty of Agriculture, Tohoku University \\ 468-1 Aramaki Aza Aoba, Aoba-ku, Sendai, Miyagi 980-0845, Japan
}

Received 24 May 2018/Accepted 13 November 2018

\begin{abstract}
A study to explore the agronomic response of some soybean genotypes to temporary flooding in the type- $B$ overflow tidal swamp and to obtain the adaptive genotype to the environment was arranged in a split-plot design at coordinates $2^{\circ} 64^{\prime} 46.77^{\prime \prime} S$ and $104^{\circ} 75^{\prime} 27.75^{\prime \prime} E$ with an altitude of $3.5 \mathrm{~m}$ above sea level. The main plot was subject to short-term flooding with a variety of cultivation technologies consisting of saturated soil culture (SSC) for one month without flooding, SSC for one month with flooding, SSC during plant growth without flooding, SSC during plant growth with flooding and non-SSC/dry cultivation. The subplot was soybean genotype consisting of 6 genotypes: Tanggamus, Karasumame (Naihou), M652, Anjasmoro, M100-47-52-13, and Tachinagaha. The result showed that impaired soybean growth at the beginning of the growth stage caused pressure on the later growth stage and decreased soybean yield. Short-term flooding reduced the soybean yield. The non-tropical genotypes of Karasumamae (Naihou), M652 and Tachinagaha produced the lowest yield of seeds; 20\% lower than the tropical genotypes of Anjasmoro, M100-47-52-13 and Tanggamus with SSC during plant growth without flooding treatment. The Karasumame (Naihou) genotype produced the highest seed yield of the three non-tropical genotypes. Anjasmoro and M100-47-52-13 produced the highest seed yield at temporary flooding.
\end{abstract}

Keywords: adaptive, marginal land, productivity, saturated soil culture, tropical genotype

\section{ABSTRAK}

Percobaan untuk mengetahui respon agronomis beberapa genotipe kedelai terhadap genangan sesaat di lahan pasang surut tipe luapan $B$ dan untuk mendapatkan genotipe yang mampu beradaptasi pada lingkungan tersebut disusun dengan rancangan petak terpisah di $2^{\circ} 64^{\prime} 46.77^{\prime \prime}$ LS and $104^{\circ} 75^{\prime} 27.75^{\prime \prime}$ BT dengan ketinggian $3.5 \mathrm{~m}$ di atas permukaan laut. Petak utama adalah genangan sesaat pada berbagai teknologi budidaya yang terdiri atas budidaya jenuh air selama 1 bulan tanpa genangan sesaat, budidaya jenuh air selama 1 bulan dengan genangan sesaat, budidaya jenuh air sepanjang umur tanaman tanpa genangan sesaat, budidaya jenuh air sepanjang umur tanaman dengan genangan sesaat dan budidaya kering. Anak petak adalah genotipe yang terdiri atas 6 genotipe yaitu Tanggamus, Karasumame (Naihou), M652, Anjasmoro, M100-4752-13, dan Tachinagaha. Hasil penelitian menunjukkan bahwa gangguan pertumbuhan kedelai pada awal pertumbuhan menimbulkan tekanan pada pertumbuhan fase selanjutnya hingga penurunan produktivitas tanaman kedelai. Genangan sesaat menurunkan pertumbuhan dan hasil kedelai. Genotipe non-tropis Karasumamae (Naihou), M652 dan Tachinagaha menghasilkan biji lebih rendah berkisar 20\% dari genotipe tropis Anjasmoro, M100-47-52-13 dan Tanggamus pada budidaya jenuh air tanpa genangan sesaat. Genotipe Karasumame (Naihou) menghasilkan biji tertinggi dari ketiga genotipe asal non-tropis. Genotipe Anjasmoro dan M100-47-52-13 merupakan genotipe yang menghasilkan biji tertinggi pada perlakuan genangan sesaat.

Kata kunci: adaptif, budidaya jenuh air, genotipe tropis, lahan marjinal, produktivitas

\footnotetext{
* Corresponding author. e-mail: iskandarlbs@yahoo.com
} 


\section{INTRODUCTION}

The positive result of researches in saturated soil culture (SSC) technology and its application in the type-C overflow tidal swamp for soybean production (Ghulamahdi et al., 2009; Noya et al., 2014a; Pujiwati et al., 2015; Endriani et al., 2018) provided an opportunity to extend soybean cultivation area to type-B. According to Noor (2004) classification, the difference between type-B and type- $\mathrm{C}$ overflow is type- $\mathrm{B}$ land is overflowed periodically by tidal water but not in type-C land. Flood in the type-B occurs during high tide.

High tides occur twice in one month, i.e., during the early moon and full moon. This tide is called a full tide (spring tide) (Imanudin et al., 2010; Surbakti, 2012; Kusmanto et al., 2016). Soybeans will experience short-term flooding at high tide. River water will inundate the land for only 3-5 hours at the peak of the tide and land will dry during low tide. Therefore, short-term flooding terminology is used in this article.

Response and mechanism of soybean adaptation to inundation stress has been studied both in the short and long-term (24 hours to 7 days) (Justino and Sodek, 2013; Kokubun, 2013; Verma and Singh, 2018). Soybean growth was disrupted by inundation. However, temporary inundation stress studies in the tidal swamp that also has low $\mathrm{pH}$ and pyrite have not been widely documented. The flooding in the tidal swamp was not only correlated with the inhibition of oxygen diffusion to/from soybean roots (Justino and Sodek, 2013), but also with the removal of dissolved pyrite, $\mathrm{Fe}$, and Al onto the soil surface. Priatmadi and Haris (2009) stated that pyrite exposed to oxygen produced an acid reaction in the soil. The response of soybean to short-term flooding will also be related to the application of saturated soil culture technology that can minimize pyrite oxidation before and after the inundation. This study aimed to find out the agronomic response of some soybean genotypes to short-term flooding under saturated soil culture in a type-B overflow tidal swamp and identify adaptive genotype to the environment.

\section{MATERIALS AND METHODS}

The experiment was conducted from April to July 2015 in the type-B overflow tidal swamp. Research location was at coordinates $2^{\circ} 64^{\prime} 46.77^{\prime \prime} \mathrm{S}$ and $104^{\circ} 75^{\prime} 27.75^{\prime \prime} \mathrm{E}$ with an altitude of $3.5 \mathrm{~m}$ above sea level. The experimental site was in the Banyuasin regency of the South Sumatera Province, Indonesia. The land was about $40 \mathrm{~km}$ from the Bangka Strait linked by Musi River.

The experiment was arranged in a split plot design with three replications. The main plot received short-term flooding on various cultivation technologies consisting of saturated soil culture (SSC) for 1 month without flooding (1M-SSC), SSC for 1 month with short-term flooding/SF (1M-SSC-SF), SSC during plant growth without flooding (SSC), and SSC during plant growth with flooding (SSC$\mathrm{SF}$ ) and dry cultivation/non-SSC (NSSC). The subplot was soybean genotype consisting of 6 genotypes namely Tanggamus (tropic/Indonesia), Karasumame (Naihou) (subtropic/Taiwan), M652 (subtropic/India), Anjasmoro (tropic/Indonesia), M100-47-52-13 (tropic/Indonesia), and Tachinagaha (Temperate/Japan). Data were analyzed by variance and Duncan Multiple Range Test (DMRT) using the STAR software versi 2.0.1.

The experimental procedure referred to the experiment of Ghulamahdi et al. (2009) with some modifications according to treatments. The flooding treatment was designed following the high tide time (Figure 1). The planting date was adjusted one day after the peak tide so that the next peak tide was estimated to be two weeks after planting (WAP). Short-term flooding was not applied after the age of 1 month. Plants were flooded for 4 hours at 14, 15 , and 16 days after planting (DAP) and 28, 29 and 30 DAP in plots that had to obtain a momentary puddle according to treatment (Figure 2).

\section{RESULTS AND DISCUSSION}

\section{Vegetative Growth of Soybean Before and After Short-term Flooding}

Cultivation technology has no significant effect on plant height on pre-SF (Figure 3). The treatment of cultivation technology on pre-SF was SSC and NSSC. 1MSSC, 1M-SSC-SF, SSC, and SSC-SF were in SSC condition on pre-SF (Figure 2). According to Ghulamahdi et al. (2009), plant age of 2-4 WAP is an acclimatization period for soybean cultivated under SSC. Soybean plants make adjustments to SSC conditions. Ethylene leaves and roots increase and causing the leaves yellow and the formation of root aerenchymas. New roots and nodules then grow significantly, and plant growth will be improved after the acclimatization period.

The performance of soybean growth at age 5 WAP (1 week after short-term flooding/WASF) grouped according

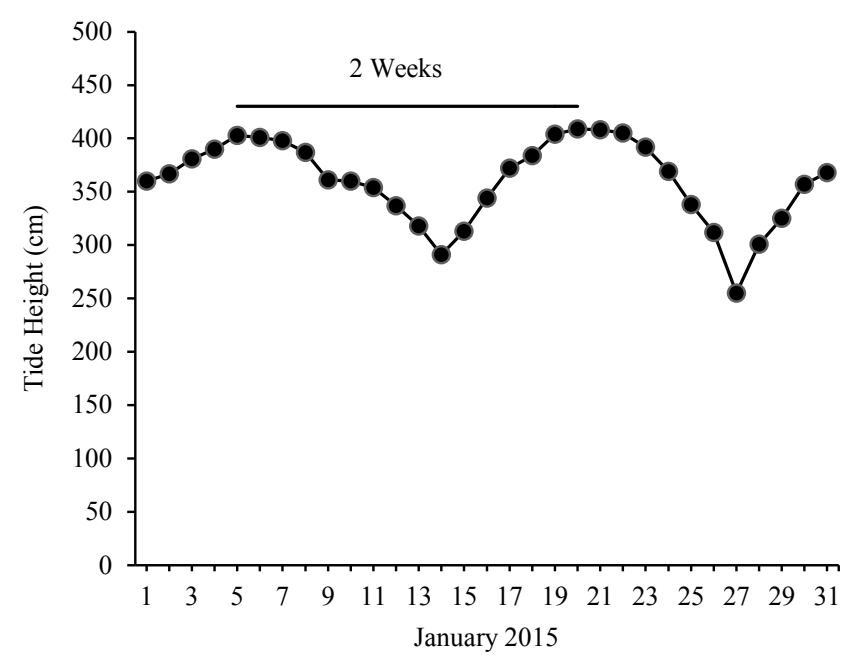

Figure 1. Daily tide height in January 2015 at Muntok Tidal Measurement Station, Bangka Belitung. Source: Geospatial Information Agency 
Non SSC

\begin{tabular}{|c|c|c|c|c|}
\hline $1 \mathrm{M}-\mathrm{SSC}$ & & & Non SSC & \\
\hline $1 \mathrm{M}-\mathrm{SSC}$ & $\mathrm{SF}$ & $\mathrm{SF}$ & Non SSC & \\
\hline \multicolumn{5}{|l|}{ SSC } \\
\hline SSC & $\begin{array}{c}\text { SF } \\
\ldots \ldots . . \\
\end{array}$ & $\begin{array}{c}\mathrm{SF} \\
\ldots \ldots \ldots \\
\end{array}$ & & \\
\hline \\
\hline Planting & $\begin{array}{c}141516 \\
\text { DAP }\end{array}$ & $\begin{array}{c}282930 \\
\text { DAP }\end{array}$ & & Harvesting \\
\hline
\end{tabular}

Figure 2. Experimental design and treatment application timeline from planting date to harvesting. Non $\mathrm{SSC}=$ dry cultivation/non saturated soil culture; $1 \mathrm{M}-\mathrm{SSC}=$ saturated soil culture for $1 \mathrm{month}$; $\mathrm{SF}=$ short-term flooding; $\mathrm{SSC}=$ saturated soil culture during plant growth; DAP = Day after planting

to the treatment of stress (Figure 3). Short-term flooding and dry cultivation caused soybean growth to be impaired as seen on the sloping growth graph from pre-SF to 1 WASF for NSSC, 1M-SSC-SF, and SSC-SF (Figure 3a). Research result of Kuswantoro (2011) showed the same soybean response pattern to the flooding namely control plants were higher than the flooding-treated plants. Justino and Sodek (2013) found that the decrease in nitrogenase activity in soybean roots began to occur 20 minutes after soybeans were subjected to inundation and increased after drainage. According to Triadiati et al. (2013), increased nitrogenase activity led to increased soybean growth. Therefore, the decrease in nitrogenase activity played a role in the slow growth of soybean when flooded.

Drought stresses on NSSC treatment in the tidal swamp could cause direct and indirect effects on soybean.
The immediate effects of drought stress on plants was metabolic processes disruption that required water such as transpiration, nutrient uptake, photosynthesis, and cell balance (Medrano et al., 2015; Jha et al., 2018). The indirect effect of drought on soybean in the tidal swamp was the oxidation of pyrite in the soil. The pores in the dry soil would be filled by oxygen. Oxygen reacted with pyrite causing a decrease in soil $\mathrm{pH}$ and elevated $\mathrm{Al}^{3+}$ levels. Soil acidity and high $\mathrm{Al}^{3+}$ levels in the soil caused impaired root growth, poor P nutrient availability, and disrupted cell integrity (Priatmadi and Haris, 2009; Abo et al., 2010; Noya et al., 2014b; Pujiwati et al., 2016).

Soybean height in NSSC, 1M-SSC-SF, and SSC-SF treatment remained below the soybean height in $1 \mathrm{M}-\mathrm{SSC}$ and SSC until harvest. Plants that experienced stress at the beginning of the growth stage were more suffering than
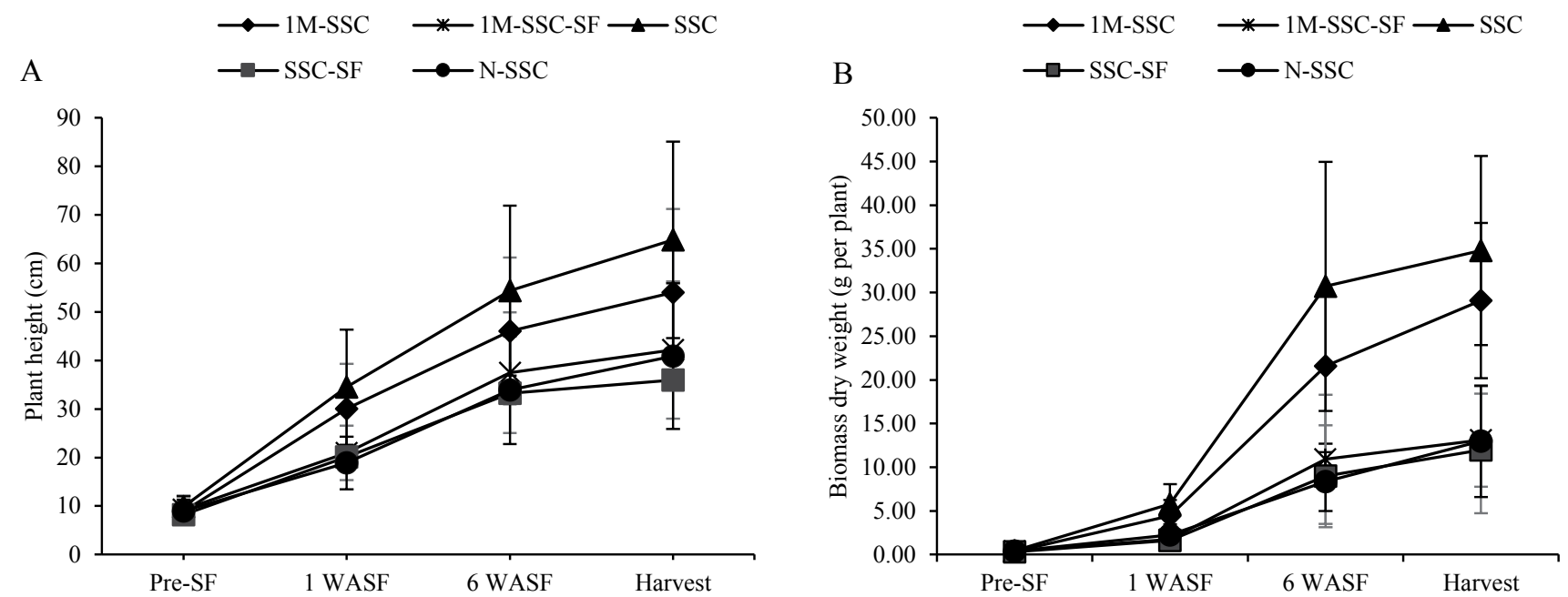

Figure 3. Mean value and standard deviation of plant height (A) and biomass dry weight (B) before and after short-term flooding treatment. $\mathrm{SF}=$ short term flooding; WASF $=$ weeks after short-term flooding treatment. $1 \mathrm{M}-\mathrm{SSC}=\mathrm{SSC}$ for 1 month without flooding; $1 \mathrm{M}$ SSC-SF = SSC for 1 month with flooding, SSC = SSC during plant growth without flooding; SSC-SF = SSC during plant growth with flooding, NSSC $=$ Non-SSC/dry cultivation 
plants that suffered stress in the advanced growth stage. Plants in the treatment of 1M-SSC experiencing drought stress after a critical period of 4 WAP so that the growth was close to the growth of SSC plant. Sagala et al. (2018) found that plants treated with $\mathrm{Al}^{3+}$ at $10 \mathrm{DAP}$ were more sensitive than those at 20 DAP. Sensitivity and root growth of $\mathrm{Al}^{3+}$-treated plants at $30 \mathrm{DAP}$ were not significantly different from control plants. The initial stage of soybean deveopment (1-20 DAP) was the critical growth stage to $\mathrm{Al}^{3+}$ stress.

Overall, it could be stated that shortening SSC application time to be one month caused a decrease in plant growth. The decreasing growth would be more significant if accompanied by temporary flooding. Under these conditions (1M-SSC-SF), soybean growth in SSC was not different from growth under dry cultivation.
Productivity and Yield Component of Soybean after Shortterm Flooding

The six soybean genotypes showed different growth responses to the type-B overflow of the tidal swamp environment (Table 1). The diversity of growth and yield responses to environments was influenced by different genetic backgrounds. The soybean genotypes originating from different countries and climatic regions: tropical, subtropical, and temperate climate region. Wirnas et al. (2012) stated that the diversity of genetic factors was essential in expressing the phenotypic performance.

All genotypes provided the highest yield in continuous SSC conditions. SSC application for only one month (1M$\mathrm{SSC}$ ) lowered the yield of almost all genotypes except

Table 1. Productivity and yield components of six soybean genotypes with short-term flooding treatment in the type-B overflow tidal swamp

\begin{tabular}{|c|c|c|c|c|c|c|}
\hline \multirow{2}{*}{$\begin{array}{l}\text { Short-term } \\
\text { flooding }\end{array}$} & \multicolumn{5}{|c|}{ Genotypes } & \multirow[b]{2}{*}{ Tanggamus } \\
\hline & Anjasmoro & Karasumame & M100-47-52-13 & M652 & Tachinagaha & \\
\hline \multicolumn{7}{|c|}{ Seed yield (ton ha $^{-1}$ ) } \\
\hline $1 \mathrm{M}-\mathrm{SSC}$ & $1.8 \mathrm{bB}$ & $1.6 \mathrm{aBC}$ & $2.4 \mathrm{aA}$ & $1.2 \mathrm{bDE}$ & $0.9 \mathrm{aE}$ & $1.4 \mathrm{bCD}$ \\
\hline 1M-SSC-SF & $1.2 \mathrm{cA}$ & $0.8 \mathrm{bAB}$ & $1.1 \mathrm{bA}$ & $0.4 \mathrm{cC}$ & $0.3 \mathrm{bC}$ & $0.5 \mathrm{cBC}$ \\
\hline $\mathrm{SSC}$ & $2.3 \mathrm{aA}$ & $1.9 \mathrm{aB}$ & $2.7 \mathrm{aA}$ & $1.7 \mathrm{aB}$ & $1.1 \mathrm{aC}$ & $2.3 \mathrm{aA}$ \\
\hline SSC-SF & $1.1 \mathrm{cA}$ & $0.9 \mathrm{bB}$ & $1.1 \mathrm{bA}$ & $0.3 \mathrm{cB}$ & $0.2 \mathrm{bB}$ & $0.4 \mathrm{cB}$ \\
\hline NSSC & $0.5 \mathrm{dA}$ & $0.5 \mathrm{bA}$ & $0.6 \mathrm{cA}$ & $0.4 \mathrm{cA}$ & $0.4 \mathrm{bA}$ & $0.3 \mathrm{cA}$ \\
\hline \multicolumn{7}{|c|}{ Node number per plant } \\
\hline $1 \mathrm{M}-\mathrm{SSC}$ & $35.7 \mathrm{aC}$ & $89.0 \mathrm{aA}$ & $30.3 \mathrm{aCD}$ & $93.3 \mathrm{aA}$ & $18.3 \mathrm{aD}$ & $70.7 \mathrm{aB}$ \\
\hline 1M-SSC-SF & $30.6 \mathrm{aB}$ & $63.3 \mathrm{bA}$ & $22.5 \mathrm{aBC}$ & $53.4 \mathrm{bA}$ & $13.5 \mathrm{aC}$ & $47.3 \mathrm{bA}$ \\
\hline $\mathrm{SSC}$ & $39.5 \mathrm{aC}$ & $98.8 \mathrm{aA}$ & $31.8 \mathrm{aCD}$ & $87.8 \mathrm{aAB}$ & $16.2 \mathrm{aD}$ & $74.1 \mathrm{aB}$ \\
\hline SSC-SF & $28.3 \mathrm{aBC}$ & $53.8 \mathrm{bA}$ & $20.7 \mathrm{aCD}$ & $37.7 \mathrm{bAB}$ & $9.8 \mathrm{aD}$ & $41.2 \mathrm{bAB}$ \\
\hline NSSC & $35.4 \mathrm{aBC}$ & $63.3 \mathrm{bA}$ & $20.6 \mathrm{aCD}$ & $43.2 \mathrm{bB}$ & $11.7 \mathrm{aD}$ & $41.4 \mathrm{bB}$ \\
\hline \multicolumn{7}{|c|}{ Pod number per plant } \\
\hline $1 \mathrm{M}-\mathrm{SSC}$ & $55.3 \mathrm{aD}$ & $112.4 \mathrm{bB}$ & $40.2 \mathrm{aDE}$ & $147.8 \mathrm{aA}$ & $22.2 \mathrm{aE}$ & $85.5 \mathrm{aC}$ \\
\hline 1M-SSC-SF & $41.3 \mathrm{aAB}$ & $58.6 \mathrm{dA}$ & $24.4 \mathrm{aBC}$ & $48.4 \mathrm{bAB}$ & $7.6 \mathrm{aC}$ & $38.1 \mathrm{bAB}$ \\
\hline $\mathrm{SSC}$ & $64.6 \mathrm{aC}$ & $144.8 \mathrm{aA}$ & $43.8 \mathrm{aCD}$ & $167.2 \mathrm{aA}$ & $20.5 \mathrm{aD}$ & $105.2 \mathrm{aB}$ \\
\hline SSC-SF & $42.0 \mathrm{aA}$ & $34.0 \mathrm{dA}$ & $20.0 \mathrm{aAB}$ & $25.0 \mathrm{bAB}$ & $4.1 \mathrm{aB}$ & $26.4 \mathrm{bAB}$ \\
\hline NSSC & $39.4 \mathrm{aB}$ & $72.5 \mathrm{cA}$ & $20.3 \mathrm{aBC}$ & $46.3 \mathrm{bAB}$ & $5.6 \mathrm{aC}$ & $40.3 \mathrm{bB}$ \\
\hline \multicolumn{7}{|c|}{ 100-grain dry weight (g) } \\
\hline $1 \mathrm{M}-\mathrm{SSC}$ & $19.8 \mathrm{aB}$ & $8.8 \mathrm{bD}$ & $16.6 \mathrm{aC}$ & $4.8 \mathrm{aE}$ & $22.2 \mathrm{bA}$ & $10.3 \mathrm{aD}$ \\
\hline 1M-SSC-SF & $18.8 \mathrm{abA}$ & $7.2 \mathrm{cE}$ & $16.6 \mathrm{aB}$ & $5.5 \mathrm{aE}$ & $14.5 \mathrm{cC}$ & $11.2 \mathrm{aD}$ \\
\hline $\mathrm{SSC}$ & $19.7 \mathrm{aB}$ & $10.9 \mathrm{aD}$ & $16.6 \mathrm{aC}$ & $5.1 \mathrm{aE}$ & $25.8 \mathrm{aA}$ & $10.7 \mathrm{aD}$ \\
\hline SSC-SF & $18.7 \mathrm{abA}$ & $5.8 \mathrm{cE}$ & $16.6 \mathrm{aB}$ & $6.1 \mathrm{aE}$ & $12.9 \mathrm{cC}$ & $9.9 \mathrm{aD}$ \\
\hline NSSC & $17.5 \mathrm{bB}$ & 9.1abD & $16.7 \mathrm{aB}$ & $5.9 \mathrm{aE}$ & $22.2 \mathrm{bA}$ & $11.3 \mathrm{aC}$ \\
\hline
\end{tabular}

Notes: Values followed by the same lowercase letters in the same column or the same uppercase letters in the same row are not significantly different in the DMRT with $\alpha=5 \%$. 1M-SSC = SSC for 1 month without flooding; $1 \mathrm{M}-\mathrm{SSC}-\mathrm{SF}=\mathrm{SSC}$ for 1 month with flooding, $\mathrm{SSC}=\mathrm{SSC}$ during plant growth without flooding; SSC-SF $=$ SSC during plant growth with flooding, NSSC = Non-SSC $/$ dry cultivation 
M100-47-52-13 which had the highest yield. Tachinagaha had the lowest yield under SSC conditions.

Short-term flooding decreased the yield of all genotypes both on SSC continuously (SSC-SF) and SSC for only one month (1M-SSC-SF). The lowest productivity was produced by NSSC treated soybean except in the M652 and Tachinagaha genotypes.

The subtropical genotype of Karasumamae (Naihou) had the potential to be developed in the type-B overflow tidal swamp with short-term flooding stress. This genotype yielded $8-66 \%$ higher seeds than Tanggamus tropical genotype, except in SSC treatment. The productivity of Tanggamus genotype with SSC treatment was 23\% higher than Karasumame genotype (Naihou). Research of Ghulamahdi et al. (2009) and Bachtiar et al. (2016) showed that Tanggamus genotype was one of the adaptive genotypes in the tidal swamp under SSC treatment. The results of this study indicated that the subtropical genotype of Karasumame (Naihou) was more adaptive than Tanggamus with shortterm flooding. The tropical genotype Tanggamus produced the lowest seed yield with short-term flooding. Noya et al. (2014a) also found that Tanggamus genotype was sensitive to environmental stress but responsive to technology input resulting in high seed yield in SSC treatment.

The genotype of M100-47-52-13 produced the highest yield in all conditions but was not statistically different from other genotypes yields in some short-term flooding treatments. Anjasmoro's yield could approach M100-47-5213 's yield unless at SSC for only one month. Anjasmoro's yield was lower than M100-47-52-13 at SSC for just one month. Under SSC, the high yield genotype was M100-4752-13, although it was not different from Anjasmoro and Tanggamus. In dry conditions, the yields of all genotypes were not different.Anjasmoro and M100-47-52-13 genotypes were the genotypes that produced the highest seed yield in the short-term flooding environment either with 1M-SSC-
SF or SSC-SF. Both genotypes originate from Indonesia.

The productivity of soybean plants was positively correlated with the yield component and nutrient uptake (Table 2). The number of nodes in the 1M-SSC and SSC treatments was generally higher than in the 1M-SSC-SF, SSC-SF, and NSSC treatments (Table 1). However, each genotype had a different response to the short-term flooding applied to SSC. Three genotypes (Anjasmoro, M100-4752-13, and Tachinagaha) produced nodes statistically that were not different in each flooding treatments. Three other genotypes (Karasumame, M652, and Tanggamus) produced significantly different number of nodes between treatments where the highest number of nodes were obtained at SSC and $1 \mathrm{M}-\mathrm{SSC}$ treatments. The number of nodes and pods are positively correlated because the pods grow from the nodes (Adie and Krisnawati, 2007). So that, in some cases, the big seed genotypes that produce few pods produced high productivity.

The correlation coefficient of nutrient uptake $(\mathrm{N}, \mathrm{P}$, $\mathrm{K})$ to soybean yield was stronger than the yield component (branch number, node number, pod number, 100-grain weight) (Table 2). The nutrient uptake of all soybean genotypes in the 1M-SSC and SSC treatments was higher than those in other treatments (Table 3). Soybean needs N, $\mathrm{P}$, and $\mathrm{K}$ nutrients in large amounts for good growth and high yield of seeds (Bachtiar et al., 2016). Bachtiar et al. (2016) stated that SSC increased nitrogenase activity, thus increased $\mathrm{N}$ uptake and improved plant growth. Nutrient uptake of the plant in tidal swamp had an essential role to the growth and development of soybean because low $\mathrm{pH}$ and high $\mathrm{Al}^{3+}$ would bind $\mathrm{P}$ to the soil matrix, so cannot be absorbed by plants (Lestari et al., 2017; Ghulamahdi et al., 2018). Noya et al. (2014a) stated that SSC could increase soil $\mathrm{pH}$ by $0.99-1.07 \mathrm{pH}$ unit and decreased $\mathrm{Al}^{3+}$ soil content by 4 me $100 \mathrm{~g}^{-1}$, so nutrient uptake $\mathrm{P}$ was increased at SSC.

Table 2. The correlation coefficient of the yield components and nutrient uptake with soybean seed yield on the short-term flooding treatment in the type-B overflow tidal swamp

\begin{tabular}{lccccccc}
\hline & Yield & $\begin{array}{c}\text { Branch } \\
\text { number }\end{array}$ & $\begin{array}{c}\text { Node } \\
\text { number }\end{array}$ & $\begin{array}{c}\text { Pod } \\
\text { number }\end{array}$ & $\begin{array}{c}100 \text {-grain } \\
\text { weight }\end{array}$ & $\begin{array}{c}\text { Leaf N } \\
\text { uptake }\end{array}$ & $\begin{array}{c}\text { Leaf P } \\
\text { uptake }\end{array}$ \\
\hline Branch number & $0.21^{*}$ & & & & & & \\
Node number & $0.29^{*}$ & $0.62^{*}$ & & & & & \\
Pod number & $0.46^{*}$ & $0.47^{*}$ & $0.90^{*}$ & & & & \\
100-grain weight & $0.22^{*}$ & $-0.37^{*}$ & $-0.65^{*}$ & $-0.45^{*}$ & & & \\
Leaf N uptake & $0.61^{*}$ & $0.46^{*}$ & $0.59^{*}$ & $0.61^{*}$ & $-0.11 \mathrm{tn}$ & & \\
Leaf P uptake & $0.57^{*}$ & $0.39^{*}$ & $0.53^{*}$ & $0.53^{*}$ & $-0.11 \mathrm{tn}$ & $0.91^{*}$ & \\
Leaf K uptake & $0.70^{*}$ & $0.32^{*}$ & $0.50^{*}$ & $0.57^{*}$ & $-0.01 \mathrm{tn}$ & $0.94^{*}$ & $0.86^{*}$ \\
\hline
\end{tabular}


Table 3. Nutrient uptake of six soybean genotypes on the short-term flooding treatment in the type-B overflow tidal swamp at 10 weeks after planting

\begin{tabular}{|c|c|c|c|c|c|c|}
\hline \multirow{2}{*}{$\begin{array}{l}\text { Short-term } \\
\text { flooding }\end{array}$} & \multicolumn{6}{|c|}{ Genotype } \\
\hline & Anjasmoro & Karasumame & M100-47-52-13 & M652 & Tachinagaha & Tanggamus \\
\hline \multicolumn{7}{|c|}{$\mathrm{N}$ uptake (g per plant) } \\
\hline $1 \mathrm{M}-\mathrm{SSC}$ & $0.24 \mathrm{abB}$ & $0.38 \mathrm{aA}$ & $0.12 \mathrm{aCD}$ & $0.17 \mathrm{aBC}$ & $0.05 \mathrm{aD}$ & $0.27 \mathrm{bB}$ \\
\hline 1M-SSC-SF & $0.13 \mathrm{bcB}$ & $0.24 \mathrm{bA}$ & $0.13 \mathrm{aAB}$ & $0.07 \mathrm{abB}$ & $0.05 \mathrm{aB}$ & $0.15 \mathrm{cAB}$ \\
\hline $\mathrm{SSC}$ & $0.33 \mathrm{aA}$ & $0.41 \mathrm{aA}$ & $0.16 \mathrm{aB}$ & $0.14 \mathrm{abB}$ & $0.04 \mathrm{aC}$ & $0.4 \mathrm{aA}$ \\
\hline SSC-SF & $0.21 \mathrm{bcA}$ & $0.13 \mathrm{bAB}$ & $0.11 \mathrm{aAB}$ & $0.04 \mathrm{bB}$ & $0.02 \mathrm{aB}$ & $0.08 \mathrm{cB}$ \\
\hline NSSC & $0.11 \mathrm{cAB}$ & $0.15 \mathrm{bA}$ & $0.09 \mathrm{aAB}$ & $0.05 \mathrm{abAB}$ & $0.03 \mathrm{aB}$ & $0.12 \mathrm{cAB}$ \\
\hline \multicolumn{7}{|c|}{ P uptake (g per plant) } \\
\hline $1 \mathrm{M}-\mathrm{SSC}$ & $0.02 \mathrm{abAB}$ & $0.02 \mathrm{bA}$ & $0.01 \mathrm{aBC}$ & $0.01 \mathrm{aAB}$ & $0.004 \mathrm{aC}$ & $0.02 \mathrm{bcA}$ \\
\hline 1M-SSC-SF & $0.01 \mathrm{bB}$ & $0.02 \mathrm{bA}$ & $0.01 \mathrm{aB}$ & $0.01 \mathrm{aB}$ & $0.005 \mathrm{aB}$ & $0.02 \mathrm{bA}$ \\
\hline $\mathrm{SSC}$ & $0.03 \mathrm{aA}$ & $0.03 \mathrm{aA}$ & $0.01 \mathrm{aB}$ & $0.01 \mathrm{aBC}$ & $0.004 \mathrm{aC}$ & $0.03 \mathrm{aA}$ \\
\hline SSC-SF & $0.02 \mathrm{bA}$ & $0.01 \mathrm{cAB}$ & $0.01 \mathrm{aAB}$ & $0.004 \mathrm{aB}$ & $0.002 \mathrm{aB}$ & $0.007 \mathrm{dAB}$ \\
\hline NSSC & $0.01 \mathrm{bA}$ & $0.01 \mathrm{cA}$ & $0.01 \mathrm{aA}$ & $0.005 \mathrm{aA}$ & $0.003 \mathrm{aA}$ & $0.011 \mathrm{cdA}$ \\
\hline \multicolumn{7}{|c|}{ K uptake (g per plant) } \\
\hline $1 \mathrm{M}-\mathrm{SSC}$ & $0.16 \mathrm{bAB}$ & $0.22 \mathrm{aA}$ & $0.11 \mathrm{abB}$ & $0.09 \mathrm{aBC}$ & $0.02 \mathrm{aC}$ & $0.12 \mathrm{bB}$ \\
\hline 1M-SSC-SF & $0.08 \mathrm{cAB}$ & $0.14 \mathrm{bA}$ & $0.07 \mathrm{bAB}$ & $0.04 \mathrm{aB}$ & $0.02 \mathrm{aB}$ & $0.07 \mathrm{bcAB}$ \\
\hline $\mathrm{SSC}$ & $0.3 \mathrm{aA}$ & $0.26 \mathrm{aAB}$ & $0.15 \mathrm{aCD}$ & $0.1 \mathrm{aD}$ & $0.02 \mathrm{aE}$ & $0.22 \mathrm{aBC}$ \\
\hline SSC-SF & $0.13 \mathrm{bcA}$ & $0.08 \mathrm{bAB}$ & $0.07 \mathrm{bAB}$ & $0.02 \mathrm{aB}$ & $0.005 \mathrm{aB}$ & $0.04 \mathrm{cB}$ \\
\hline NSSC & $0.07 \mathrm{cA}$ & $0.08 \mathrm{bAB}$ & $0.06 \mathrm{bA}$ & $0.02 \mathrm{aA}$ & $0.008 \mathrm{aA}$ & $0.07 \mathrm{bcA}$ \\
\hline
\end{tabular}

Notes: Values followed by the same lowercase letters in the same column or the same uppercase letters in the same row are not significantly different in the DMRT test of the $\alpha=5 \%$. 1M-SSC $=$ SSC for 1 month without flooding; 1M-SSC-SF $=$ SSC for 1 month with flooding, SSC = SSC during plant growth without flooding; SSC-SF = SSC during plant growth with flooding, NSSC $=$ Non-SSC/ dry cultivation.

\section{CONCLUSION}

The growth of soybean between SSC and NSSC treatments did not differ during acclimatization (2 WAP). The growth of soybean decreased one week after short-term flooding treatment (5 WAP). Impaired soybean growth at the beginning of growth caused pressure on the growth of the next stage and decreased yield. The genotype of M10047-52-13, originating from a tropical region, produced the highest yield in all conditions. However, it was not statistically different from other genotypes yields in some short-term flooding treatments. The yield of Karasumame (Naihou) genotype was the highest of the three non-tropical genotypes. The Karasumamae (Naihou) genotype seed yield was $8-66 \%$ higher than the tropical genotype of Tanggamus except in SSC treatment. Anjasmoro and M100-47-52-13 genotypes are the genotypes that produced the most seeds in the treatment of temporary inundation.

\section{ACKNOWLEDGMENT}

This study was part of a doctoral dissertation of Doctoral Program in IPB Graduate School funded by Graduate Program Scholarship (BPPDN), Indonesia.

\section{REFERENCES}

Abo M., H. Yonehara, E. Yoshimura. 2010. Aluminum stress increases carbon-centered radicals in soybean roots. J. Plant Physiol. 167:1316-1319.

Adie, M.M., A. Krisnawati. 2007. Biologi tanaman kedelai. p. 45-73. In: Sumarno, Suyamto, A. Widjono, Hermanto, H. Kasim (Ed.). Kedelai-Teknik Produksi dan Pengembangan. Puslitbangtan, Balitbang, Deptan, Bogor, ID.

Bachtiar, M. Ghulamahdi, M. Melati, D. Guntoro, A. Sutandi. 2016. Kebutuhan nitrogen tanaman kedelai pada tanah mineral dan mineral bergambut dengan budi daya jenuh air. Penelit. Pertan. Tanam. Pangan $35: 217-227$.

Endriani, M. Ghulamahdi, E. Sulistyono. 2018. Pertumbuhan dan hasil kedelai di lahan rawa lebak dengan aplikasi pupuk hayati dan kimia. J. Agron. Indonesia 45:263270 . 
Ghulamahdi, M., M. Melati, D. Sagala. 2009. Production of soybean varieties under saturated soil culture on tidal swamps. J. Agron. Indonesia 37:226-232.

Ghulamahdi, M., H.D. Welly, D. Sagala. 2018. Nutrient uptake, growth and productivity of soybean cultivars at two water depths under saturated soil culture in tidal swamps. Pak. J. Nutr. 17:124-130.

Imanudin, M.S., E. Armanto, R.H. Susanto, S.M. Bernas. 2010. Water table fluctuation in tidal lowland for developing. J. Trop. Soils 15:277-282.

Jha P.K., S.N. Kumar, A.V.M. Ines. 2018. Responses of soybean to water stress and supplemental irrigation in upper Indo-Gangetic plain: Field experiment and modeling approach. F. Crop. Res. 219:76-86.

Justino, G.C., L. Sodek. 2013. Recovery of nitrogen fixation after short-term flooding of the nodulated root system of soybean. J. Plant Physiol. 170:235-241.

Kokubun, M. 2013. Genetic and cultural improvement of soybean for waterlogged conditions in Asia. Field Crops Res. 152:3-7.

Kusmanto, E., M. Hasanudin, W.B. Setyawan. 2016. Amplifikasi pasang surut dan dampaknya terhadap perairan pesisir Probolinggo. Oseanol. Limnol. Indonesia 1:69-80.

Kuswantoro, H. 2011. Response of soybean genotypes to waterlogging. J. Agron. Indonesia 39:19-23.

Lestari, T., Trikoesoemaningtyas, S.W. Ardie, D. Sopandie. 2017. Peranan fosfor dalam meningkatkan toleransi tanaman sorgum terhadap cekaman aluminium. J. Agron. Indonesia 45:43-48.

Medrano, H., M. Tomás, S. Martorell, J. Flexas, E. Hernández, J. Rosselló, A. Pou, J.M. Escalona, J. Bota. 2015. From leaf to whole-plant water use efficiency (WUE) in complex canopies: Limitations of leaf WUE as a selection target. Crop J. 3:220-228.

Noor, M. 2004. Lahan Rawa: Sifat dan Pengelolaan Tanah Bermasalah Sulfat Masam. Raja Grafindo Persada. Jakarta, ID.
Noya, A.I., M. Ghulamahdi, D. Sopandie, A. Sutandi, M. Melati. 2014a. Pengaruh kedalaman muka air dan amelioran terhadap produktivitas kedelai di lahan sulfat masam. Pangan 23:120-132.

Noya, A.I., M. Ghulamahdi, D. Sopandie, A. Sutandi, M. Melati. 2014b. Interactive effects of aluminum and iron on several soybean genotypes grown in nutrient solution. Asian J. Plant Sci. 13:18-25.

Priatmadi, B.J., A. Haris. 2009. Reaksi pemasaman senyawa pirit pada tanah rawa pasang surut. J. Tanah Trop. 14:19-24.

Pujiwati, H., M. Ghulamahdi, S. Yahya, S.A. Aziz, O. Haridjaja. 2015. The application of peaty mineral soil water in improving the adaptability of black soybean toward aluminium stress on tidal mineral soil with saturated soil culture. J. Agric. Sci. Agrivita 37:284289.

Pujiwati H, M. Ghulamahdi, S. Yahya, S.A. Aziz, O. Haridjaja. 2016. Tanggap kedelai hitam terhadap cekaman aluminium pada kultur hara. J. Penelit. Pertan. Tan. Pangan 35:149-153.

Sagala, D., E. Suzanna, Prihanani, M. Ghulamahdi, I. Lubis, Trikoesoemaningtyas. 2018. Effect of aluminum stress in early-stage growth of soybean. IOP Conf. Ser. Earth Environ. Sci. 144:012067.

Surbakti, H. 2012. Karakteristik pasang surut dan pola arus di muara sungai musi, Sumatera Selatan. J. Penel. Sains 15:35-39.

Triadiati, N.R. Mubarik, Y. Ramasita. 2013. Respon pertumbunan tanaman kedelai terhadap Bradyrhizobium japonicum toleran masam dan pemberian pupuk di tanah masam. J. Agron. Indonesia 41:24-31.

Verma, K.K., M. Singh. 2018. Flooding stress in a changing environment. Asian J. Bot. 1:1-11.

Wirnas, D., Trikoesoemaningtyas, H.S. Sutjahjo, D. Sopandie, W.R. Rohaeni, S. Marwiyah, Sumiati. 2012. Keragaman karakter komponen hasil dan hasil pada genotipe kedelai hitam. J. Agron. Indonesia 40:184-189. 